\title{
3D MODELING OF THE ARCHAIC AMPHORAS OF IONIA
}

\author{
A. Denker ${ }^{\text {a }}$, H. Oniz ${ }^{\text {b, }}$ \\ ${ }^{a}$ Istanbul Bilgi University, 34060 Eyup Istanbul, Turkey \\ ahmet.denker@bilgi.edu.tr \\ ${ }^{\mathrm{b}}$ Selcuk University, Konya, Turkey \\ hakan.oniz@gmail.com
}

Commission V

KEY WORDS: Amphoras, Archaic Period, Ionia, 3D Modeling

\begin{abstract}
:
Few other regions offer such a rich collection of amphoras than the cities of Ionia. Throughout history amphoras of these cities had been spread all over the Mediterranean. Despite their common characteristics, amphora manufacturing cities of Ionia had their own distinctive styles that can be identified. They differed in details of shape and decoration. Each city produced an authentic type of amphora which served as a trademark of itself and enabled its attribution to where it originated from. That's why, amphoras provide important insight into commerce of old ages and yield evidence into ancient sailing routes. Owing to this our knowledge of the ancient trade is profoundly enriched. The following is based on the finds of amphoras which originated from the Ionian cities of Chios, Clazomenai, Lesbos, Miletus, and Samos. Starting from city-specific forms which offer interpretative advantages in provenancing, this article surveys the salient features of the regional forms and styles of the those Ionian cities. 3D modeling is utilized with the aim of bringing fresh glimpses of the investigated amphoras by showing how they originally looked. Due to their virtual indestructibility these models offer interpretative advantages by enabling experimental testing of hypotheses upon the finds without risking them. The 3D models in the following sections were reconstructed from numerous fragments of necks, handles, body sherds and bases. They convey in color- unlike the monochrome drawings which we were accustomed to-the texture, decoration, tint and the vitality of the amphoras of Ionia.
\end{abstract}

\section{INTRODUCTION}

Over a period of three centuries, during the Archaic Period (800-480 BC), Ionian cities were among the most prolific centers of Amphora production. These centers not only produced large number of amphoras but also gave them different styles which is of interest in revealing geographical and chronological traces. The streamlined figures of amphoras with two handles alongside the neck and pointed bottoms have been among of the best recognised shapes of the world since the first quarter of the $7^{\text {th }}$ century BC.

This shape was imposed by its functionality and it was what gave the vessel its well known name. The name amphora is

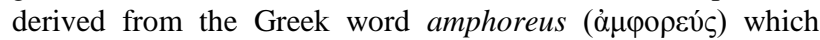
means a container with two carrying handles on both sides. The handles and the pointed tip were there to allow robust carrying, easy pouring and decanting the contents of the jar. Despite these common characteristics, amphora manufacturing cities of Ionia had their own distinctive styles that a trained eye can discern without much toil.

Most amphoras (excluding the grey vessels of Lesbos) shared the common fabric of reddish brown clay and had the same specific outline in appearance. Notwithstanding these common features they differed in details of shape and embellishment. These differences stemmed from local stylistic choices, as well as incentives for distinction from the vessels of the other cities. Working clay into an amphora involved balancing various local values and priorities. Each center fabricated an authentic type of amphora which served as a trademark of its city and enabled its attribution to where it originated from.

This article surveys the salient features of the regional forms and styles of the Ionian cities of Chios, Clazomenai, Lesbos, Miletus, and Samos (Figure 1), in the archaic period. The work addresses the analyses based on city- specific forms which offer interpretative advantages in provenancing. Understanding the details of these forms casts light on the distinguishing values and priorities of the producer community. It then goes on to establish the geographical and chronological differences through modeling these amphoras by using 3D visualization techniques. The 3D models which we believe to be the most faithful reconstructions of the surveyed amphoras are the outcomes of a multidisciplinary teamwork which span the fields of underwater archaeology and computer graphics.

Firm establishment of these differences is important to nautical archaeology. Through the years amphoras littered the Aegean sea bottom. An amphora on the seabed signifies the identity of the home port of a wreck based on its typology. In addition, amphoras of known provenance are good indicators of who was trading with whom. Moreover, the physical robustness of amphoras make them one of the most consistently preserved objects in the archaeological records. Their widespread survival means we can hope to implement them as tracers of the elusive social and economic lives of the ancient civilizations

\footnotetext{
* Corresponding author
} 


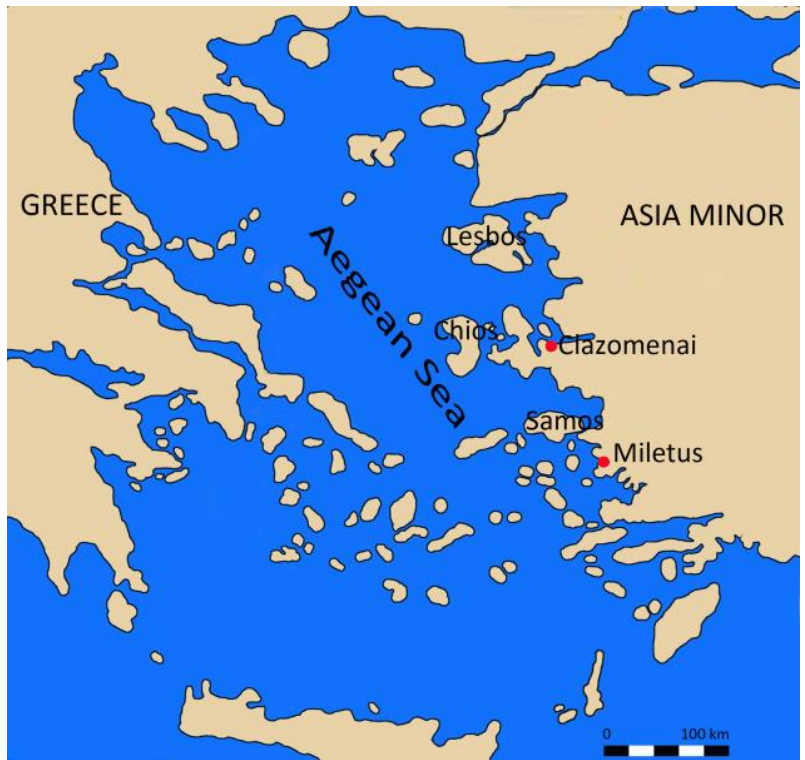

Figure 1. Ionian centers of amphora production in the Archaic Period

\section{CITY SPECIFIC FORM AND STYLE}

\subsection{Significance of the City-Specific Form and Style}

Thanks to modern underwater archaeological expeditions, amphoras have been discovered in large numbers not only at the coasts of Chios, Clazomenai, Lesbos, Miletus, and Samos, but all over the Mediterranean. As more amphora workshops became known we had ample evidence that these Ionian cities were the major amphora production centres over the span of the Archaic Period. While more amphoras were discovered and more different amphora types were isolated the regional styles of these cities could be identified in detail and truly specific relationships between the shape of the amphora and the fabricating city could be established with more confidence.

Studies of these amphoras usually lead to a direct connection between the shape of the amphora and its city of origin. The figure and style of the amphora was like the badge or trademark of the city. They were frequently illustrated on coins of cities such as Chios and Samos. Their appearance on the coins of the cities may be taken as the latitude of the civic interest in the amphora production in these centers. The link between the city and the amphora type is further emphasized by the emergence of specific names given to amphoras in the Ionian region. Thus Chios, Clazomenai, Lesbos, Miletus, and Samos were used to refer to particular jars which originated from these cities. These containers emerged at the beginning of the Archaic Period and reached their distinctive form over the span of this era.

\section{3D MODELING OF AMPHORAS}

The prodigious power of $3 \mathrm{D}$ modeling in helping us to reconstruct and visualize a new the artefacts that the archaeologists had recovered has already been well recognized (Forte, Siliotti, 1997). In this article 3D modeling is utilized with the aim of bringing fresh glimpses of the investigated amphoras by showing how they originally looked. Due to their virtual indestructibility these models offer interpretative advantages by enabling experimental testing of hypotheses upon the finds without risking them.

The 3D models in the following sections were reconstructed from numerous fragments of necks, handles, body sherds and bases. They convey in color -unlike the monochrome drawings which we were accustomed to- the texture, decoration, tint and the vitality of the amphoras of Ionia.

\section{AMPHORAS OF IONIA}

Few other regions offer such a rich collection of amphoras than the cities of Ionia. Throughout history they have been spread all over the Mediterranean. The archaeological information that can be harnessed from this wealth is impressive. The following is based on the finds of the cities of Chios, Clazomenai, Lesbos, Miletus, and Samos. The detailed information about the cited amphora pieces is provided in Appendix .

\subsection{Chian and Clazomenian Amphoras}

First examples of a unique Ionian amphora type began to appear in the second half of the $7^{\text {th }}$ century BC. They had originated from the workshops of either Chios or Clazomenai. Throughout the archaic period both Chios and Clazomenai were the most prolific amphora production centres of Ionia. A number of vessels had been extricated from sea bottom or unearthed which are dated to a span of time from mid $7^{\text {th }}$ century BC to early $5^{\text {th }}$ century BC. These vessels kept their salient typological and decorative characteristics over two centuries which made them recognizable without toil. However, these characteristics had undergone some variations over the time. The manufacturers in both cities seem to have had spent efforts to create amphora styles which help identify the city where they came from. Subsequent to the discovery of a unique amphora type on a Chian coin V. Grace (Grace, 1979) identified a group of ovoid shaped clay jars as Chian amphoras at the beginning of 1930's. This type is known for the $\sim$ motives on the shoulder. Figure 2 shows the $3 \mathrm{D}$ recoconstruction a Chian amphora which is dated to $650 \mathrm{BC}$. It has a bulbous bellied body decorated with four horizontal glaze bands. Three of these bands stay closer to each other and form a group just under the $\checkmark$ motive, whereas the fourth one stands alone in the middle of the belly.

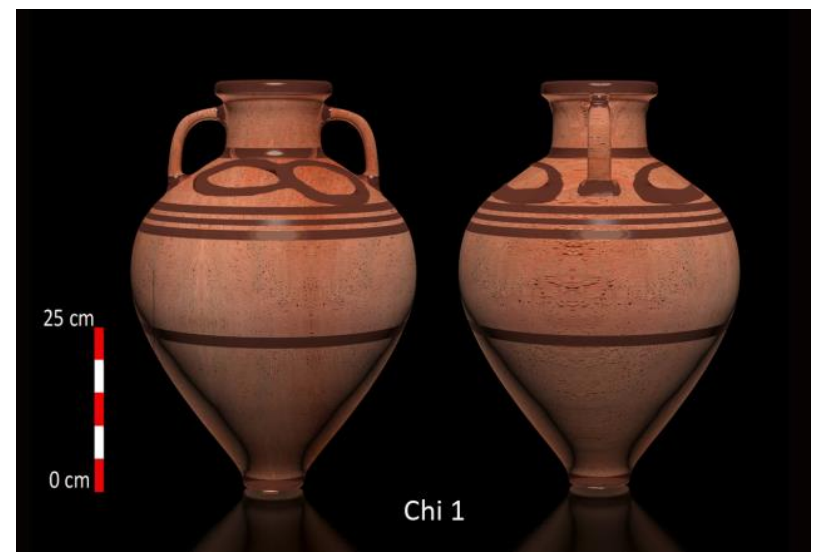

Figure 2. 3D model of a Chian amphora from $650 \mathrm{BC}$. 
Its arched handles are attached to the body as well as the squat neck. A glaze circle band encircles each junction. Most of the Chian amphoras of this period had glaze bands around their rims as well as along the neck-shoulder binding. In some cases there were even diagonal glaze bands or intersecting diagonal glaze bonds. Figure 3 shows a group of Chian amphoras from 650$600 \mathrm{BC}$

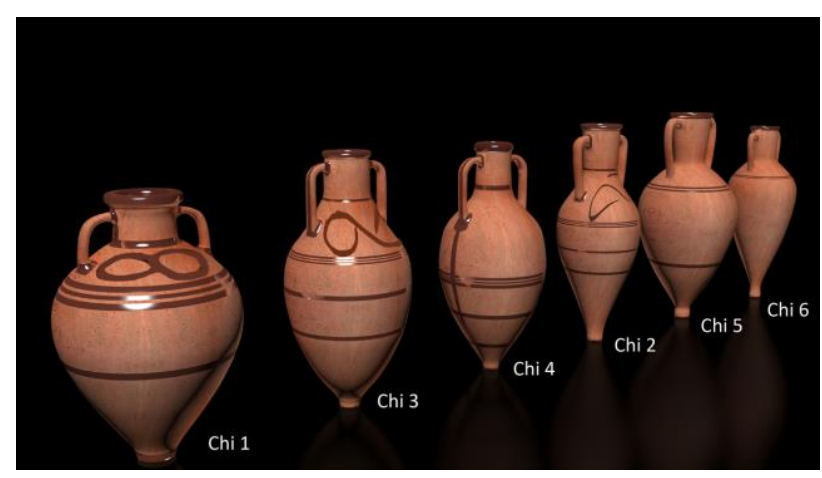

Figure 3. A group of Chian amphoras from $650-600 \mathrm{BC}$.

Clazomenia was an important port of wine trading. Clazomenian amphora manufactures in the second half of the $7^{\text {th }}$ century used the same decorative schemes as Chians. Similar embellishment themes of $\sim$ motives on the shoulder, and horizontal glaze stripes around the rim, shoulder and belly were also implemented by Clazomenian masters. (Figure 4). This made it difficult to separate one from another. However, most of the times these stripes were broader than the Chian counterparts. That's why some authors called them as 'amphoras with broad bands', (Zeest, 1960).

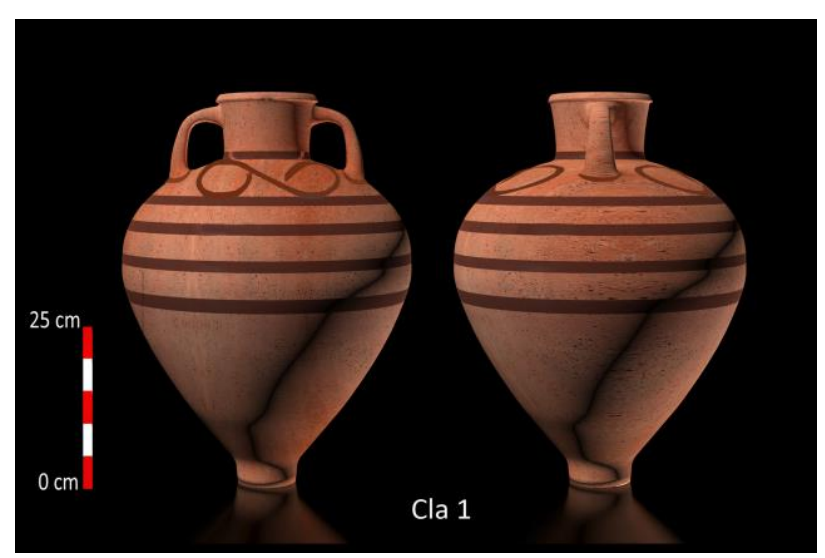

Figure 4. 3D model of a Clazomenian amphoras from $650 \mathrm{BC}$.

Allied to this close resemblance, the earlier pieces of recovered Clazomenian amphoras were used to be attributed to Chios. However, D. Dupont isolated Clazomenai as a different center of amphora production (Dupont, P., 1998). Dupont's findings were reinforced by Doger's discoveries (Doger, 1991) and Clazomenai was established conclusively as a separate center of
Ionian amphora production in the Archaic Period. In his book Y. Sezgin (Sezgin, 2012) provided a catalogue of these amphoras.

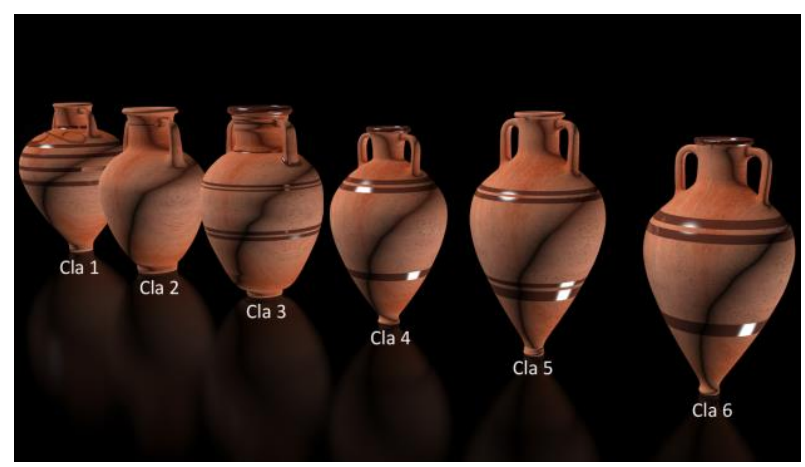

Figure 5. A group of Clazomenian amphoras

from $650-600 \mathrm{BC}$.

Starting from the the $6^{\text {th }}$ century B.C. Chian and Clazomenian amphoras had begun to drift away from each other. Afterwards, Chian and Clazomenian products could easily be separated from each other. Clazomenians ceased using the $\sim$ figure on the shoulders of their vessels, from then on $\checkmark$ figure was only implemented by Chians as an identification mark. Although Chians had kept $\sim$ figure they made other distinctive changes in both shape and decoration.

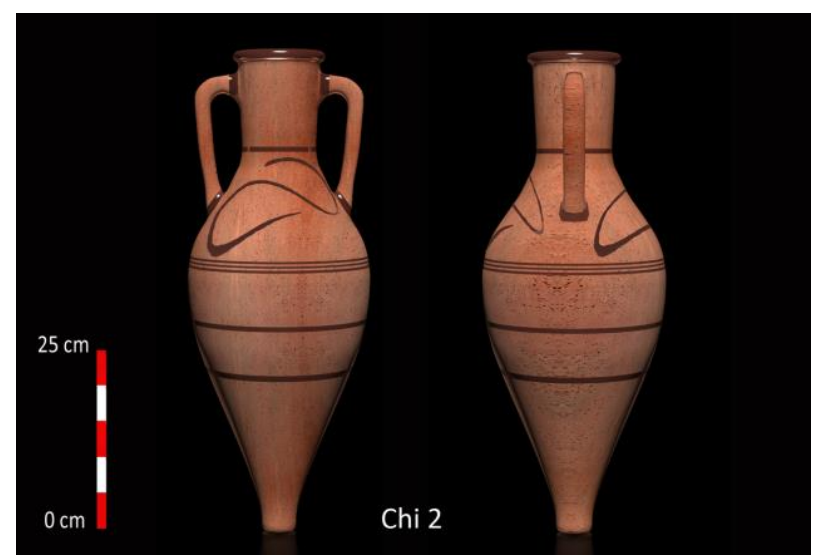

Figure 6. A Chian amphora with a slender and tall body from 575-550 BC.

Squat necks and bulbous bellies were discontinued, and a new type of Chian amphora was created with a slender and tall body (Figure 6). In this new type, a round rim sits over a long neck which is flanked with stirrup amphora handles.

A Clazomenian product of the same period is shown in Figure 7. It exhibits a pleasing form. A round mushroom-shaped rim stands on a semi-long neck which flares out towards the shoulder. The body widens down the shoulder with a gentle slope and has a depression below the belly towards a short stem toe. The body is decorated with two pairs of dark red glaze bands. The one closest to the toe is wider than the other three. 


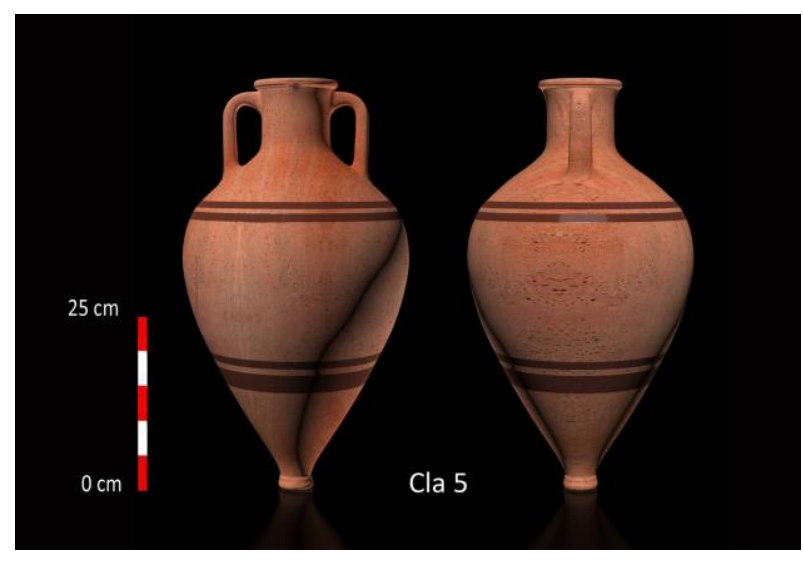

Figure 7. A Clazomenian amphora from the same period

\subsection{Lesbian Amphoras}

Lesbos Island was another important center of amphora producion in the archaic period. Amphora production started in Lesbos in the $7^{\text {th }}$ century, contemporarily with Chios and Clazomenia. However, contrary to the former two types whose similarity caused confusion, Lesbian amphoras had an unusual feature which rendered them easily identifiable: unlike the Chian and Clazomenian examples which were predominantly of warmer earth colors, the color of some Lesbian amphoras was grey. Since no examples of red Lesbian amphoras were encountered at the beginning, one can presume that amphora production in Lesbos had started with grey amphoras.

Earliest red Lesbian amphoras did not appear before the last quarter of the $8^{\text {th }}$ century BC. From $6^{\text {th }}$ century onwards both grey and red Lesbian amphoras followed the same lines of development in shape. Red Lesbian amphoras ceased at the end of the $5^{\text {th }}$ century BC. However, grey Lesbian amphoras continued until the $3^{\text {th }}$ century BC. Figure 8 depicts a red Lesbian amphora from an epoch between the last quarter of the $6^{\text {th }}$ century and the $1^{\text {st }}$ quarter of the $5^{\text {th }}$ century.

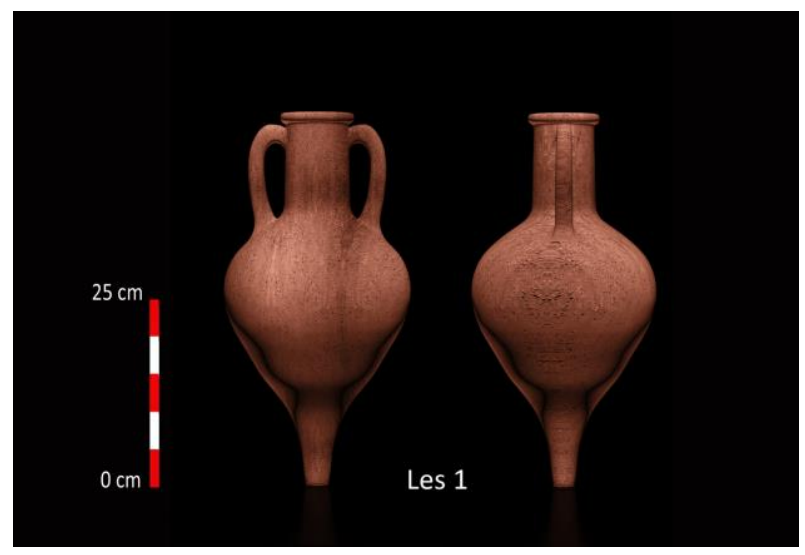

Figure 8. A red Lesbian Amphora which is dated between the last quarter of the $6^{\text {th }}$ century and the $1^{\text {st }}$ quarter of the $5^{\text {th }}$ century.
Excluding its common red color, it displays other distinguishing features of a Lesbian amphora : a distinct shape in the form of Greek letter 'phi', bulged necks, cylindrical handles with "rat tail" like relief line, and a bulbous belly which ends in an elongated toe. Lower body steeply narrows towards the toe.

The cane-shaped handles seen in this figure are slightly pushed towards the neck before being attached to the shoulders. The red tail relief starts immediately above this attachment point. Another distinguishing feature of this amphora is its rather tall neck.

The grey amphora which started to take place in the scene of commerce as of the middle of the $7^{\text {th }}$ century continued to dominate the markets till the middle of the $5^{\text {th }}$ century.

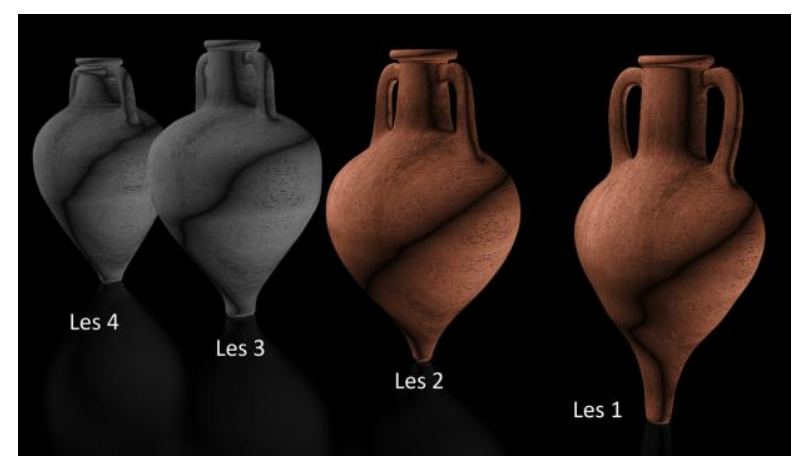

Figure 9 Two red and two grey Lesbian amphoras from the period $7^{\text {th }}-5^{\text {th }}$ century BC

\subsection{Milesian Amphoras}

Miletus was one of the leading centers of Ionia. Thanks to its privileged location, it was an important center of commerce in the archaic period. The city was wealthy, its prosperity was primarily due to agricultural products. Oil and wine production played a profound role in city's prosperity. As evidenced by widespread Milesian amphoras in the Eastern Mediterranean, Miletus was also a leading pottery manufacturer and an important hub of amphora production.

Like the amphora producers of the former Ionian cities, producers of Miletos also spent effort in order to create a distinct amphora form which would make it easy to identify the vessel as a Milesian amphora.

Excavations had revealed a number of amphoras which resembled those from the island of Samos. They were characterized by the distinguished feature of thickened rim lips. Grace (Grace, 1971) isolated this type as 'Milesian'. Laboratory analyses confirmed that Grace was right. Milesian amphora had indeed a shape of its own which evolved separately from the Samian shape over a long period. This shape is above all characterized by a thick lip surrounding the rim, and ridges on transition from rim to neck. In majority of the Milesian examples there is only one rim, however examples with two or three ridges had also been found. In addition, there is a ridge or groove on neck-shoulder transition. Miletus has also examples with decorative dark red stripes (Figure 10). 


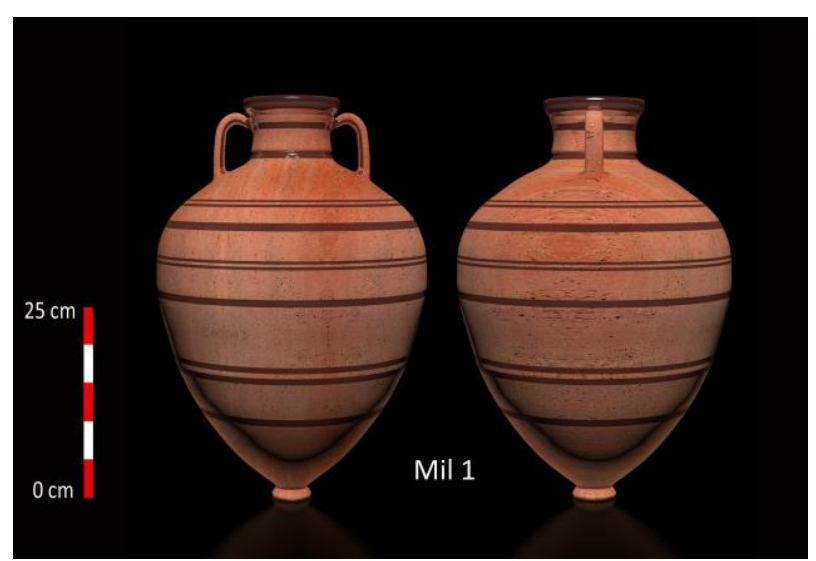

Figure 10. A Milesian amphora from $6^{\text {th }}$ century BC.

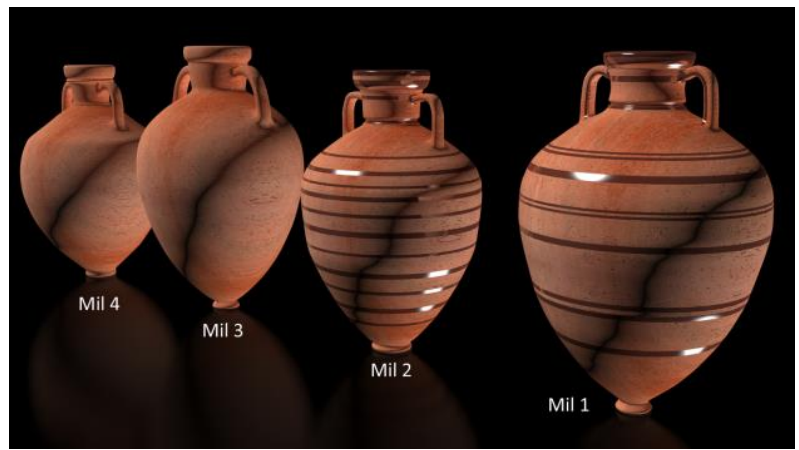

Figure 11. Milesian amphoras from $7^{\text {th }}-5^{\text {th }}$ century BC.

\subsection{Samian Amphoras}

We owe the first data about Samian amphoras to W.M.F. Petrie (Petrie, 1886, 1888, 1909) and J.Boehlau (Boehlau,1898). However, the credit also goes to Iredia Zeest (Zeest, 1960) for the identification of 'Samian' as a separate type. She isolated this type with a protruding cornice rim, cylindrical neck, ovoid body and bevelled ring foot as 'Samian amphora'. V.Grace (Grace, 1971) published a comprehensive study about Samian amphoras. The typological classification which was put forward in Grace's work is still met with universal acceptance. Figure 12 shows a Samian amphora from 550-500 BC.

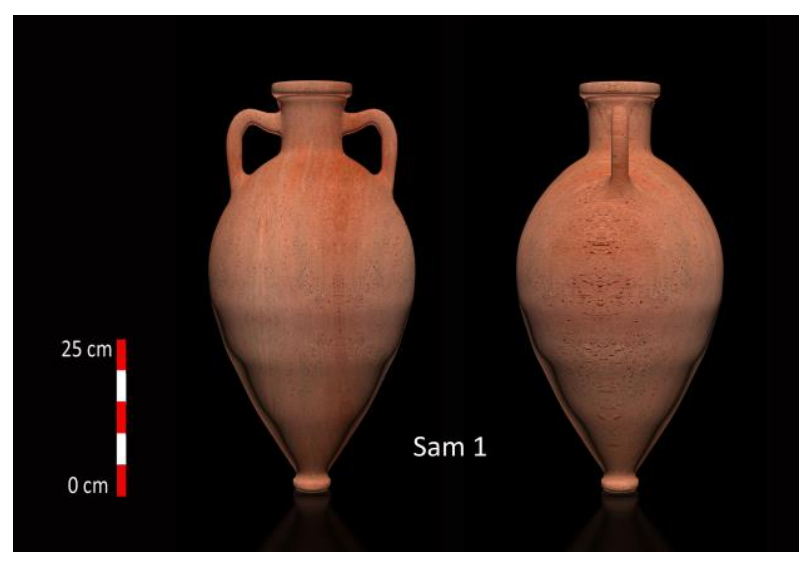

Figure 12. A Samian amphora from 550-500 BC.

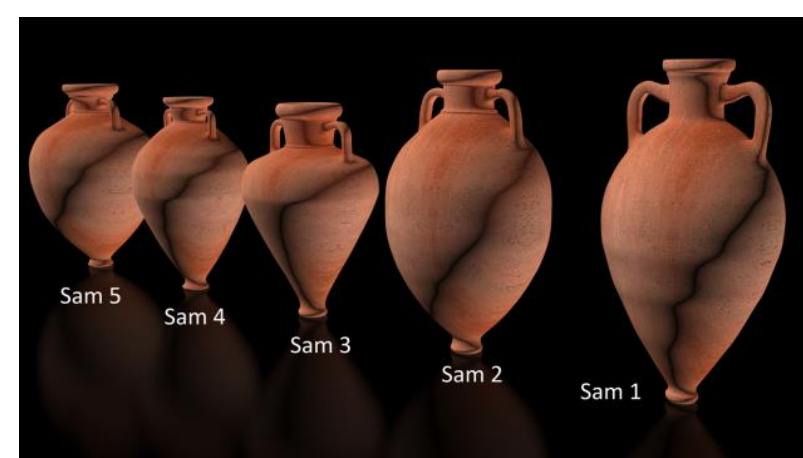

Figure 13. A group Samian amphoras from $7^{\text {th }}-5^{\text {th }}$ century BC.

A tendency towards a narrower and taller type can be seen here compared to the earlier types which are shown in Figure 13.

\section{CONCLUSION}

Numerous amphoras have been found at the coasts of Chios, Clazomenai, Lesbos, Miletus, and Samos which provide important insight into ancient maritime activity in this region and furnish evidence into ancient sailing routes. Owing to these finds our knowledge of the ancient maritime trade and harbors have been conspicuously enriched. Crucial clues provided by them are not limited to maritime trade. Shape, size and weights of the discovered amphoras yield attributes of the vessels, as well. They also have stories to tell about the shipwrecks.

Additionally, there was copious material in this region for tracing the development of amphoras from the viewpoint of craftsmanship. Finds make it possible to follow evolution in the shapes of many classes of amphoras.

Underwater cultural heritage of the waters in this part of the world are facing new risks because of industry, tourism and some of SCUBA diving activities like many of other countries. Recognizing the urgent need to preserve and protect such heritage, creating scientific data of the cultural values of these depths becomes more and more important. The possibilities that are increasingly being created by advances in $3 \mathrm{D}$ modelling are opening new windows for the creation and preservation of the data pertaining to the ancient maritime activity. As the technological progress strides on, we are able to reconstruct and achieve visualization of the amphoras as in their original appearances.

In this work, 3D models of the archaic amphoras of Ionia which reproduce the virtual aspects, as objects of archaic maritime life in Ionia, are presented. The presented examples include 3D models of amphoras from Chios, Clazomenai, Lesbos, Miletus, and Samos, from $650 \mathrm{BC}$ to $450 \mathrm{BC}$. These results show that 3D modelling is a much more complete methodology of reconstructing and recording the past than traditional methodologies of photography and drawing.

\section{ACKNOWLEDGEMENTS}

Authors gratefully acknowledge the support of Izmir Archaeology Museum, and Sadberk Hanim Museum. Thanks 
are also due to Civan Berk Gencan for his contribution in 3D graphics.

\section{REFERENCES}

Birzescu, I., 2009. Drei Typen archaischer Reifenamphoren aus Milet, $A A$ 2009/1, 121-134.

Boehlau, J.,1898. Aus Ionischen und Italianischen Nekropolen, Leipzig.

Bound, M, 1991, The Pre-Classical Wreck at Campese Bay, Island of Giglio, Second Interim Report 1983 Season, Paoli F. (ed.), Studi e Materiali.Scienza dell' antichita in Toscana, Vol. VI, L'Erma di Bretschneider, Roma, 181-198.

Campell, M. ,1938, A Well of the Black-Figured Period at Corinth, Hesperia 7-4, 557-611.

Cook, R.M., Dupont, P. 1998. East Greek Pottery, London/ New York.

Doger, E., 1988. Klazomenai Kazısındaki Arkaik Donem Ticari Amforalar, Ph. D. Thesis, Izmir.

Doger, E., 1991. Antik Çağda Amforalar, Izmir.

Dupont, P., 1982. Amphores commerciales archaichques de la Grece de l'Est, $P P$ 37, 193-209.

Forte, M., Siliotti, A., 1997. Virtual Archaeology: Re-creating Ancient Worlds, Harry N. Abrams Inc., Spain.

Gjerstad, E., Pottery from various parts of Cyprus, Greek Geometric and Archaic Pottery Found in Cyprus, Stockholm, 23-60.

Grace, V., 1971. Samian Amphoras, Hesperia 40,

Grace, V., 1979, Amphoras and the Wine Trade, Excavations of the Athenian Agora, Picture Book, No.6, Revised Edition, American School of Classical Studies at Athens.

Haggis et al, 2007, Excavations at Azorio, 2003-2004, Part I, The archaic civic complex, Hesperia 76, 243-321.

Kachavara, D., 1995, Greek Imports of Archaic and Classical Times in Colchis, $A A, 63-73$.

Karageorghis, V., 1962, Chronique des fouilles et decouvertes archeologiques a Chypre en 1961, BCH 86, 327-414.

Karageorghis, V., 1970, Chronique des fouilles et decouvertes archeologiques a Chypre en 1968, BCH 93, 431-569.

Melyukova, A.I., 1980. Porselenie Nadlimanskoe II na beregu Dnestrovskogo limana, Issledovaniia po antichnoi archeologii yugo- Zapada Ukrainskoii SSR:sbornik nauchnykh trudov, Kiev, 5-23.

Petrie W.M.F., 1886. Naukratis I, London.

Roberts, R.S., Glock, A., 1986. The Stoa gutter well, a late archaic deposit in the Athenian Agora, Hesperia 55, 1-72.
Rizzo M.A., 1990. Complessi tombali dall'Etruria meridionale, Le anfore da transporto e il cmmercio etrusco arcaico I, Rome.

Skarlatidou, E., 2004, The archaic cemetery of the Clazomenian Colony of Abdera, Klazomenai, Teos and Abdera:Metropoleis and Colony. Proceedings of the International Symposium held at the Archaeological Museum of Abdera, 2001,Thesaloniki, 249-259.

Sezgin, Y., 2012. Arkaik Dönem İonia Üretimi Ticari Amforalar, Ege yayınları.

Tiverios, M., 2008. Greek Colonisation of the Northern Aegean, Tsetskhladze G.R. (ed.) Greek colonization An account of Greek Colonies and Other Settlements Overseas, Vol. 2, Mnemosyne, Supplementa 193, Boston, 1-54.

Zeest, I. B., 1960. Keramicheskaia tara Bosfora, MIA 83.

\section{APPENDIX}

Data about each of the Ionion amphoras included in this paper are provided below, dimensions are given in metric system.

\section{A.1 Chian Amphoras}

\section{Chi 1 (Fig. 2)}

Diameter of rim: $\quad 13.9 \mathrm{~cm}$

Height: $\quad 60.0 \mathrm{~cm}$

Height of neck: $\quad 9.8 \mathrm{~cm}$

Diameter of belly: $39.0 \mathrm{~cm}$

Depth of foot: $\quad 0.5 \mathrm{~cm}$

Date: $\quad 650 \mathrm{BC}$

Find site: Cerveteri, Banditaccia Necropolis

Source: $\quad$ Rizzo, 1990

\section{Chi 2 (Fig. 6)}

Diameter of rim: $\quad 11.8 \mathrm{~cm}$

Height: $\quad 66.0 \mathrm{~cm}$

Height of neck: $\quad 15.0 \mathrm{~cm}$

Diameter of belly: $24.9 \mathrm{~cm}$

Date: $\quad 575-550 \mathrm{BC}$

Find site: Marion, Chrysochou

Source: Karageorghis,1962

\section{Chi 3 (Fig. 3)}

Diameter of rim: $\quad 11.8 \mathrm{~cm}$

Height: $\quad \quad 70.0 \mathrm{~cm}$

Height of neck: $\quad 14.0 \mathrm{~cm}$

Diameter of belly: $32.9 \mathrm{~cm}$

Date: $\quad$ Late $7^{\text {th }}$-Early $6^{\text {th }}$ century BC

Location: Michaelides collection, Cyprus

Source: Karageorghis, 1969

\section{Chi 4 (Fig. 3)}

Diameter of rim: $\quad 13.0 \mathrm{~cm}$

Height: $\quad \quad 70.0 \mathrm{~cm}$

Height of neck: $\quad 13.3 \mathrm{~cm}$

Diameter of belly: $36.4 \mathrm{~cm}$ 
Date:

Find Site:

Source:

Late $7^{\text {th }}$-Early $6^{\text {th }}$ century BC

Bayrakl1, İzmir

Chi 5 (Fig. 3)

Diameter of rim: $\quad 10.5 \mathrm{~cm}$

Height: $\quad 64.0 \mathrm{~cm}$

Height of neck: $\quad 14.3 \mathrm{~cm}$

Diameter of belly: $25.8 \mathrm{~cm}$

Date: $\quad 575-550 \mathrm{BC}$

Location: Marion

Source: $\quad$ Gjerstad,1977

Chi 6 (Fig. 3)

Diameter of rim: $\quad 12.2 \mathrm{~cm}$

Height: $\quad 76.5 \mathrm{~cm}$

Height of neck: $\quad 14.9 \mathrm{~cm}$

Diameter of belly: $31.0 \mathrm{~cm}$

Date: $\quad 490 \mathrm{BC}$

Find Site: Corinth

Source: Campell,1938

\section{A.2 Clazomenian Amphoras}

\section{Cla 1 (Fig. 4)}

Diameter of rim: $\quad 13.0 \mathrm{~cm}$

Height: $\quad 63.0 \mathrm{~cm}$

Height of neck: $\quad 10.0 \mathrm{~cm}$

Diameter of belly: $44.5 \mathrm{~cm}$

Depth of foot: $\quad 0.5 \mathrm{~cm}$

Date: $\quad 650 \mathrm{BC}$

Find Site: $\quad$ Abdera Necropolis

Source: $\quad$ Skarlatidou,2004 and Tiverios, 2008

\section{Cla 2 (Fig. 5)}

Diameter of rim: $\quad 17.0 \mathrm{~cm}$

Height: $\quad 64.5 \mathrm{~cm}$

Height of neck: $\quad 15.0 \mathrm{~cm}$

Diameter of belly: $41.5 \mathrm{~cm}$

Depth of foot: $\quad 0.5 \mathrm{~cm}$

Date: $\quad 650-620 \mathrm{BC}$

Find Site: $\quad$ Clazomenai, Kalabak II Necropolis

Source: $\quad$ Doger, 1988

\section{Cla 3 (Fig. 5}

Diameter of rim: $\quad 18.5 \mathrm{~cm}$

Height: $\quad 62.5 \mathrm{~cm}$

Height of neck: $\quad 14.5 \mathrm{~cm}$

Diameter of belly: $44.0 \mathrm{~cm}$

Date: $\quad 650-620 \mathrm{BC}$

Find Site: $\quad$ Clazomenai, Kalabak II Necropolis

Source: $\quad$ Doger, 1988

\section{Cla 4 (Fig. 5)}

Diameter of rim: $\quad 12.8 \mathrm{~cm}$

Height: $\quad 67.0 \mathrm{~cm}$

Height of neck: $\quad 9.3 \mathrm{~cm}$

Diameter of belly: $40.0 \mathrm{~cm}$

Depth of foot: $\quad 2.4 \mathrm{~cm}$

Width of stripe: $\quad 2.5 \mathrm{~cm}$

Date:

Find Site:

Source:

\author{
Cla 5 (Fig. 7) \\ Diameter of rim: $\quad 10.0 \mathrm{~cm}$ \\ Height: $\quad 63.4 \mathrm{~cm}$ \\ Height of neck: $\quad 9.9 \mathrm{~cm}$ \\ Diameter of belly: $34.5 \mathrm{~cm}$ \\ Date: $\quad 520-480 \mathrm{BC}$ \\ Find Site: $\quad$ Athenian Agora, Attolas Stoa \\ Source: $\quad$ Roberts and Glock, 1986
}

\section{Cla 6 (Fig. 5)}

Diameter of rim: $\quad 12.5 \mathrm{~cm}$

Height: $\quad 61.0 \mathrm{~cm}$

Height of neck: $\quad 9.7 \mathrm{~cm}$

Diameter of belly: $34.5 \mathrm{~cm}$

Depth of foot: $\quad 2.8 \mathrm{~cm}$

Date: $\quad 550-490 / 480 \mathrm{BC}$

Find Site: $\quad$ Salamis

Source: $\quad$ Karageorghis,1970

\section{A.3 Lesbian Amphoras}

Les 1 (Fig. 8)

Diameter of rim: $\quad 9.0 \mathrm{~cm}$

Height: $\quad 47.0 \mathrm{~cm}$

Height of neck: $\quad 14.5 \mathrm{~cm}$

Diameter of belly: $22.1 \mathrm{~cm}$

Color: $\quad$ Red

Date: Late $6^{\text {th }}$ century- Early $5^{\text {th }}$ century BC

Find site: Nadlimanskoe

Source: $\quad$ Melyukova,1980

\section{Les 2 (Fig. 9)}

Diameter of rim: $\quad 9.0 \mathrm{~cm}$

Height: $\quad 47.0 \mathrm{~cm}$

Height of neck: $\quad 10.3 \mathrm{~cm}$

Diameter of belly: $26.7 \mathrm{~cm}$

Color: $\quad$ Red

Date: $\quad 5^{\text {th }}$ century BC

Find site: $\quad$ Pichnavaria Necropolis

Source: Kachavara, 1995

\section{Les 3 (Fig. 9)}

Diameter of rim: $\quad 11.5 \mathrm{~cm}$

Height: $\quad 62.5 \mathrm{~cm}$

Height of neck: $\quad 14.9 \mathrm{~cm}$

Diameter of belly: $38.5 \mathrm{~cm}$

Depth of foot: $\quad 0.5 \mathrm{~cm}$

Color: Grey

Date: 550-500 BC

Find site: Unknown

Source: $\quad$ Sadberk Hanim Museum

Les 4 (Fig. 9)

Diameter of rim: $\quad 12.0 \mathrm{~cm}$

Height: $\quad 66.7 \mathrm{~cm}$

Height of neck: $\quad 13.5 \mathrm{~cm}$

Diameter of Belly: $41.2 \mathrm{~cm}$

Dept of foot: $\quad 1.5 \mathrm{~cm}$

Date: 600-550 BC

Find site: $\quad$ Bayrakli,Izmir

Source: $\quad$ Izmir Archaeology Museum 


\section{A.4 Milesian Amphoras}

Mil 1 (Fig. 10)

Diameter of rim: $\quad 10.5 \mathrm{~cm}$

Height: $\quad 52.0 \mathrm{~cm}$

Height of neck: $\quad 7.2 \mathrm{~cm}$

Diameter of belly: $34.5 \mathrm{~cm}$

Depth of foot : $\quad 0.7 \mathrm{~cm}$

Date: $\quad 2^{\text {nd }}$ half of $6^{\text {th }}$ century BC

Find site: Miletus

Source: $\quad$ Birzescu,2009

\section{Mil 2 (Fig. 11)}

Diameter of rim: $\quad 13.4 \mathrm{~cm}$

Height: $\quad 49.5 \mathrm{~cm}$

Height of neck: $\quad 9.3 \mathrm{~cm}$

Diameter of belly: $26.7 \mathrm{~cm}$

Color: Red

Date: $\quad 5^{\text {th }}$ century BC

Find site: Pichnavaria Necropolis

Source: Kachavara, 1995

\section{Mil 3 (Fig. 11)}

Diameter of rim: $\quad 11.5 \mathrm{~cm}$

Height: $\quad 62.5 \mathrm{~cm}$

Height of neck: $\quad 14.9 \mathrm{~cm}$

Diameter of belly: $38.5 \mathrm{~cm}$

Depth of foot: $\quad 0.5 \mathrm{~cm}$

Color: $\quad$ Grey

Date: 550-500 BC

Find site: $\quad$ Unknown

Source: $\quad$ Sadberk Hanim Museum

\section{Mil 4 (Fig. 11)}

Diameter of rim: $\quad 12.0 \mathrm{~cm}$

Height: $\quad 66.7 \mathrm{~cm}$

Height of neck: $\quad 13.5 \mathrm{~cm}$

Diameter of belly: $41.2 \mathrm{~cm}$

Depth of foot: $\quad 1.5 \mathrm{~cm}$

Date:

Find site:

600-550 BC

Bayrakli,Izmir

Source: $\quad$ Izmir Archaeology Museum

\section{A.4 Samian Amphoras}

Sam 1 (Fig. 12)

Height: $\quad 67.5 \mathrm{~cm}$

Diameter of belly: $34.0 \mathrm{~cm}$

Depth of foot : $\quad 0.1 \mathrm{~cm}$

Date: $\quad 2^{\text {nd }}$ half of $6^{\text {th }}$ century BC

Find site: Klazomenai

Source: $\quad$ Doger,1988

\section{Sam 2 (Fig. 13)}

Diameter of rim: $\quad 13.0 \mathrm{~cm}$

Height: $\quad 58.0 \mathrm{~cm}$

Height of neck: $\quad 8.7 \mathrm{~cm}$

Diameter of belly: $37.6 \mathrm{~cm}$

Date: late $6^{\text {th }}$ century BC

Find site: $\quad$ Azoria, Crete

Source: Haggis et al, 2007

\section{Sam 3 (Fig. 13)}

Diameter of rim: $\quad 11.9 \mathrm{~cm}$

Height: $\quad 43.9 \mathrm{~cm}$

Height of neck: $\quad 6.7 \mathrm{~cm}$

Diameter of belly: $28.0 \mathrm{~cm}$

Depth of foot: $\quad 0.5 \mathrm{~cm}$

Date: $\quad 600 \mathrm{BC}$

Find site: $\quad$ Giglio wreck

Source: $\quad$ Bound, 1991

\section{Sam 4 (Fig. 13)}

Diameter of rim: $\quad 11.5 \mathrm{~cm}$

Height: $\quad 53.0 \mathrm{~cm}$

Height of neck: $\quad 06.2 \mathrm{~cm}$

Diameter of belly: $35.0 \mathrm{~cm}$

Depth of foot: $\quad 1.1 \mathrm{~cm}$

Date: $\quad$ 590-560 BC

Find site: $\quad$ Montalo di Castro, Tomba

Source: $\quad$ Rizzo, 1990

Sam 5 (Fig. 13)

Diameter of rim: $\quad 14.4 \mathrm{~cm}$

Height: $\quad 53.5 \mathrm{~cm}$

Height of neck: $\quad 6.5 \mathrm{~cm}$

Diameter of belly: $37.2 \mathrm{~cm}$

Depth of foot: $\quad 0.8 \mathrm{~cm}$

Date: 600-550 BC

Find site: $\quad$ Vulci, Osteria

Source: $\quad$ Rizzo, 1990 